\title{
GIF NATURAL RADIOCARBON MEASUREMENTS III
}

\author{
G. DELIBRIAS, M. T. GUILLIER, and J. LABEYRIE
}

Centre des Faibles Radioactivités, Centre National de la Recherche Scientifique, 91, Gir-sur-Yvette, France

The dates detailed below are a selection of $\mathrm{C}^{14}$ dates obtained from February 1966 to December 1967 for geologic samples. The method is essentially the same as described previously in Radiocarbon, 1966, v. 8 p. 74-95. All samples were subjected to pretreatment, differing in individual cases, to remove contamination. On one of our three installations, modern transistorized equipment replaced the original electronics.

All dates reported have been calculated on the assumed half-life of $5568 \mathrm{yr}$ for $\mathrm{C}^{14}$, and of 1950 as the reference year.

\section{ACKNOWLEDGMENTS}

We should like to thank Inès Mirre for routine sample preparation and Michel Jaudon for assistance with electronic equipment.

\section{SAMPLE DESCRIPTIONS}

\section{GEOLOGIC SAMPLES}

\section{A. France}

\section{Normandy sea shore series}

Tangue is loose sediment consisting of silty sand, with clay and abundant remains of marine shells (total $\mathrm{Ca} \mathrm{Co}_{3}: 40$ to $48 \%$ ), and fine organic particles (ca. $1 \%$ of total weight) commonly deposited on SW coasts of Normandy. Tangues dated here are, at present, overlain by sand dunes or forming outcrops on strand, at different alts. Coll. and subm. 1965 by P. Giresse, Fac. Sci., Caen, Calvados.

\section{Gif-387. Heugueville, 885}

$1470 \pm 120$

Tangue from bed $2 \mathrm{~m}$ thick, in estuary of Sienne R., at Heugueville $\left(18^{\circ} 53^{\prime} \mathrm{N}\right.$ Lat, $1^{\circ} 40^{\prime} \mathrm{W}$ Long), ca. $3 \mathrm{~m}$ above sea high tide level.

\section{Gif-388. Pontorson}

$1250 \pm 120$

Very fine clayey tangue, $40 \mathrm{~cm}$ thick, under $2 \mathrm{~m}$ coarse tangue, which comes from alluvium of Couesnon R. in Bay of Mont Saint-Michel, near Pontorson (48 $34^{\prime} \mathrm{N}$ Lat, $1^{\circ} 30^{\prime} \mathrm{W}$ Long). Top of coarse tangue is at high tide level.

\section{Gif-389. Saint-Jean-Le Thomas}

$1430 \pm 120$

Tangue, $20 \mathrm{~cm}$ thick, underlain by $115 \mathrm{~cm}$ wind-blown sand, at Saint-Jean-Le Thomas ( $48^{\circ} 44^{\prime} \mathrm{N}$ Lat, $1^{\circ} 31^{\prime} \mathrm{W}$ Long), in Bay of MontSaint-Michel, ca. high tide level. 
Gif-390. Hauteville, 2

Outcrop of shelly sand, $15 \mathrm{~cm}$ thick, discovered by erosion, on strand at Hauteville $\left(48^{\circ} 52^{\prime} \mathrm{N}\right.$ Lat, $1^{\circ} 33^{\prime} \mathrm{W}$ Long), under $20 \mathrm{~cm}$ tangue, $0.5 \mathrm{~m}$ under sea high tide level.

\section{Gif-391. Hauteville, 1}

$1680 \pm 120$

Glayey tangue just above Gif-390; at ca. sea high tide level. General Comment: most of the samples have been dated from fine organic particles of tangue (except Gif-390, dated from shells). J. Labeyrie suggests that Gif-387, ca. $3 \mathrm{~m}$ above other tangue deposits of series, could be eolian. On the contrary, Giresse et al. (1967) suggest that it is only known deposit of Dunkerkian transgression in Normandy.

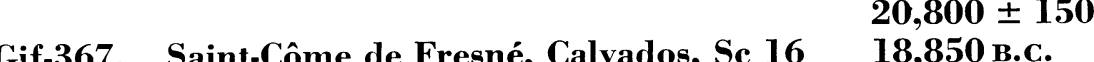

Peat from boring at Saint-Côme de Fresné $\left(49^{\circ} 20^{\prime} \mathrm{N}\right.$ Lat, $0^{\circ} 37^{\prime}$ W Long), on coast of The Channel, Calvados; under $6.30 \mathrm{~m}$ yellow silt and $1 \mathrm{~m}$ gray clay, lying on calcareous bed rock; alt: mean sea level (士 $0.5 \mathrm{~m}$ ). Coll. and subm. 1965 by C. Larsonneur, Fac Sci., Caen, Calvados. Comment: pollen analysis indicates cold climate (Pinus minimum); belongs to Würm III (Delibrias and Larsonneur, 1966).

\section{Gif-368. Ecalgrain, Manche, H 4}

Outcrop of peaty clay from Baie d'Ecalgrain, in Hague $\left(49^{\circ} 44^{\prime} \mathrm{N}\right.$ Lat, $1^{\circ} 54^{\prime}$ W Long), Manche, alt: $+5 \mathrm{~m}$ above mean sea level; covered by important consolidated solifluction flows which overlap surface. Coll. and subm. 1965 by C. Larsonneur. Comment: pollen stratigraphic position: Pinus maximum (Elhaï, 1962).

\section{Gif-369. Vauville, Manche, H 8}

$21,940 \pm 1500$ 19,990 в.c.

Outcrop of peaty clay on strand, covered in some places by sand bar, alt: mean sea level ( $\pm 0.5 \mathrm{~m})$, Vauville $\left(49^{\circ} 38^{\prime} \mathrm{N}\right.$ Lat, $1^{\circ} 50^{\prime} \mathrm{W}$ Long), Manche. Coll. and subm. 1965 by C. Larsonneur. Comment: pollen analysis shows predominance of Cyperaceae and Gramineae indicating rather cold climate conditions.

\section{Gif-370. Herquemoulin, Manche, $\mathbf{H} 7$}

Peat on sandy clay, on shore, alt: mean sea level $( \pm 0.5 \mathrm{~m})$ at Herquemoulin (49. $39^{\prime} \mathrm{N}$ Lat, $1^{\circ} 54^{\prime} \mathrm{W}$ Long), Manche. Coll. and subm. 1965 by C. Larsonneur. Comment: absence of pollen; structure similar to Gif-368.

\section{Asnelles series, Calvados}

Peat beds separated by clayey levels, from Boring 1, Asnelles, Ca:vados $\left(49^{\circ} 20^{\prime} \mathrm{N}\right.$ Lat, $0^{\circ} 34^{\prime} \mathrm{W}$ Long). Alt at top of boring: $+0.35 \mathrm{~m}$ above mean sea level. Coll. and subm. by C. Larsonneur. 
Gif-371. Asnelles, AS 2

$5680 \pm 250$

3910 B.c.

Peat with some fresh water gastropods, from $20 \mathrm{~cm}$ below surface. Pollen stratigraphic position: Quercus and Alnus dominant. Coll. and subm. 1965.

Gif-728. Asnelles, AS 13

$8320 \pm 200$

\section{Peat from 115 cm below surface. Between this sample and B.c.}

of $70 \mathrm{~cm}$ of gray clay. Coll. and subm. 1966. Pollen stratigraphic position: beginning of Quercus.

Gif-372. Asnelles, AS 3

$8710 \pm 350$ 6760 в.c.

Peat from $150 \mathrm{~cm}$ below surface. Pollen stratigraphic position: Corylus abundant. Coll. and subm. 1965.

\section{Gif-729. Asnelles, AS 20}

$10,100 \pm 230$

Peat from $175 \mathrm{~cm}$ below surface. Coll. and subm. 1966. Pollen stratigraphic position: Pinus and Betula dominant.

General Comment: bog shows very coherent series of postglacial deposits. These lst dates permit calculation of high rate of turbification ca. 8,000 B.P. and corroborate conclusions obtained from pollen analysis.

\section{Gathemo series, Normandy}

Peat samples from bog, at Gathemo, $\mathrm{S}$ of Vire $\left(48^{\circ} 58^{\prime} \mathrm{N}\right.$ Lat, $0^{\circ} 53^{\prime}$ W Long), Normandy; alt $330 \mathrm{~m}$. Dated to determine ages of phases of clearing in region. Coll. and subm. 1964 by H. Elhaï, Inst. Geog., Paris.

\section{Gif-402. Gathemo 6}

Coll. $1965,0.90$ to $1 \mathrm{~m}$ under surface.

Gif-403. Gathemo 7

Coll. 1965 , 1.90 to $2 \mathrm{~m}$ depth.

\section{Gif-137. Gathemo 8}

Coll. 1961, 2.30 to $2.40 \mathrm{~m}$ depth.

General Comment: Gif-403 and Gif-137 agree with pollen analysis; Gif137 is just above clearing level, giving palynological evidence of Atlantic period (Elhaï, 1960). Gif-402 seems too young.

\section{Picardie series}

Channel coast of Picardie is open and flat country with recent sedimentation between estuaries of Somme and La Conche Rivers. Hand borings in maritime marsh behind small sandy dunes revealed peaty levels separated by fluvial deposits and marine sand. These peats are now $4 \mathrm{~km}$ behind beach and dunes. Altitudes are related to mean sea level. Coll. 
and subm. 1965, by J. Etienne and P. Robert, Co. d'Exploitation Pétrol. Chambourcy, Seine et Oise.

Gif-396. Merlimont, ML 1 bis, $19 \mathrm{~m}$

$\left(50^{\circ} 24^{\prime} \mathrm{N}\right.$ Lat, $1^{\circ} 35^{\prime} \mathrm{E}$ Long). Bed of peat; alt $-9 \mathrm{~m}$.

\section{Gif-397. Merlimont, ML 1 bis, 8.50 m depth} Peaty clay, $+1 \mathrm{~m}$.

Gif-398. Pont du Curé, PC 1, 8.40 m depth $\left(50^{\circ} 24^{\prime} \mathrm{N}\right.$ Lat, $1^{\circ} 36^{\prime} \mathrm{E}$ Long). Peaty clay: alt $-3 \mathrm{~m}$.

Gif-399. Pont du Curé, PC 1, $4.50 \mathrm{~m}$ depth $3720 \pm 200$ 1770 B.c.

Peaty clay: alt $+1 \mathrm{~m}$.

Gif $761 . \quad 8430 \pm 200$ $\left(50^{\circ} 28^{\prime} \mathrm{N}\right.$ Lat, $1^{\circ} 38^{\prime} \mathrm{E}$ Long). Humus sand; alt $+2 \mathrm{~m}$.

Gif-762. Berck-Plage, 25671

A.D. 1390

$560 \pm 95$

$\left(50^{\circ} 23^{\prime} \mathrm{N}\right.$ Lat, $1^{\circ} 34^{\prime} \mathrm{E}$ Long). Outcrop of sandy humus with clay. at foot of eroded dune, at high tide level.

Gif-763 bis. Fort-Mahon, FM 2 bis, 22 m depth $7980 \pm 190$ 6030 B.c. $\left(50^{\circ} 22^{\prime} \mathrm{N}\right.$ Lat, $\mathrm{I}^{\circ} 36^{\prime} \mathrm{E}$ Long). Peat, $7 \mathrm{~cm}$ thick; alt $-17 \mathrm{~m}$.

\section{Gif-764. Fort-Mahon, FM 4, 21 m depth}

Dusty peat; alt $-16 \mathrm{~m}$.

7800 B.C.

General Comment (P.R.): very good concordance between $\mathrm{C}^{14}$ dates and pollen study along cores: these data added to sedimentologic study of region reflect history of formation of Picardie plain. Between 11,500 and 7500 B.P., sea had not yet reached Picardie plain, but local rise of mean river levels promoted spreading of fluvial estuary deposits; ca. 5000) B.P., sea covered region, and greatly eroded older deposits. Consistent with similar study on Holland littoral (Van Straaten, 1965).

\section{Evian series, Haute Savoie}

Some peaty levels have been found during borings to study water level at Evian $\left(46^{\circ} 24^{\prime} \mathrm{N}\right.$ Lat, $6^{\circ} 35^{\prime} \mathrm{E}$ Long), Haute Savoie. Evian, on Lake Geneva is at $\mathrm{N}$ of Vinzier plateau which is cut in SW part by Dranse Valley. Region was overspread by Rhône glacier during last glaciation. Although $214 \mathrm{~m}$ deep, deepest boring through plateau has only crossed Quaternary formations and not encountered bedrock. The 3 borings studied showed interstadial sediments of different facies and unequal thickness included in moraines. Upper moraine from 50 to $85 \mathrm{~m}$ 
thick. Coll. 1964 by B. Blavoux and subm. by L. Glangeaud, Lab. Geol. Dynamique, Sorbonne, Paris.

\section{Gif-333. Boring Sionnex, S 1 (12); $\quad 23,500 \pm 1200$ alt $728 \mathrm{~m}$ $\mathbf{2 1 , 5 5 0 ~ в . C . ~}$}

Fragments of branches at $31.5 \mathrm{~m}$ depth, in black clay, $25 \mathrm{~cm}$ thick, at base of "interstadial" formation.

\section{Gif-334. Boring Sionnex, S 1 (52) \\ $26,200 \pm 1200$}

Debris of branches and leaves at $104 \mathrm{~m}$ depth, in silt, $75 \mathrm{~cm}$ thick.

\section{Gif-335. Boring Sionnex, S 1 (93)}

$24,900 \pm 1200$

Pieces of wood with debris of branches at $186.5 \mathrm{~m} \mathrm{depth}$, in silt and thin sand, $50 \mathrm{~cm}$ thick.

\section{Gif-336. Boring Royal, S 2 (33); alt $467 \mathrm{~m}$} thick.

Branches with many leaves, at $63.5 \mathrm{~m}$ depth, in thin sand, $20 \mathrm{~cm}$

General Comment: dates indicate that both moraine levels belong to Würm and that, more precisely, interstadial formations correspond to Würm III-IV. Pollen analyses show important variations of proportion of pines vs. herbs (Brun and Blavoux, 1966).

Gif-491. Armoy R. G. 25 B, Haute Savoie $\geqslant 35,000$

Woody material in interstadial ligniferous level, in cliff; alt $480 \mathrm{~m}$ at Armoy, Dranse valley, Haute Savoie ( $46^{\circ} 22^{\prime} \mathrm{N}$ Lat, $6^{\circ} 30^{\prime} \mathrm{E}$ Long). From top, $15 \mathrm{~m}$ thick gravel, pebbles and sand, $35 \mathrm{~m}$ glacio-lacustrine moraine and $25 \mathrm{~m}$ interstadial lacustrine sand and clay including some ligneous remains at upper level. Coll. 1965 and subm. 1966 by A. Brun, Lab. Geol. Dynamique, Sorbonne, Paris.

Gif-739. Armoy R. G. D 58, Haute Savoie

Wood from same level as Gif-491. Coll. 1965 and subm. 1966 by A. Brun. Comment for Gif-739 and Gif-491: dates and stratigraphic considerations permit relation of Armoy Interstadial to Würm II-III. Good correlations with stratigraphic and pollen analysis results obtained for Evian series (Brun and Delibrias, 1967).

\section{Gif-774. Thonon-les-Bains, T 1, Haute-Savoie 12,050 в.c.}

Fragments of Elephas primigenius molar found in gravel pit, 1.5 $\mathrm{km} \mathrm{SE}$ of Thonon-les-Bains ( $46^{\circ} 20^{\prime} \mathrm{N}$ Lat, $6^{\circ} 28^{\prime} \mathrm{W}$ Long). Subm. 1966 by A. Brun. Comment: tooth comes from late-Würm gravel deposits at top of glacial complex studied in Dranse valley (Armoy) and Vinzier plateau (borings at Evian). Collagen fraction extracted for dating. 
Gif-386. La Balme, Savoie

Fragment of branch of giant oak tree; $2 \mathrm{~m}$ diam, $31 \mathrm{~m}$ long, 55 tons, in alluvium of Rhône bed, at La Balme ( $46^{\circ} 02^{\prime} \mathrm{N}$ Lat, $\left.6^{\circ} 58^{\prime} \mathrm{E} \mathrm{Long}\right)$, Savoie. Coll. 1883 and subm. 1965 by L. Lagier Bruno, Yenne, Savoie.

Gif-490. Lac Léman, L 66-395

$3910 \pm 400$

Fragment of wood at $3.95 \mathrm{~m}$ depth in sediments of Lac Léman (Lake Geneva), off Lausanne (46 $26^{\circ} \mathrm{N}$ Lat, $6^{\circ} 29^{\prime} \mathrm{E}$ Long). Coll. and subm. 1966 by C. Serruya, Centre de Recherches Géodynamiques, Thonon-lesBains. Comment: date indicates speed of sedimentation of $1 \mathrm{~m}$ per 1000 yr which seems correct for lacustrine environment (Serruya and Sauvage, 1966). Sample mixed with dead gas for counting.

\section{Ballon d'Alsace series, Vosges}

Peat from 2 peat bogs of Ballon d'Alsace $\left(47^{\circ} 49^{\prime} \mathrm{N}\right.$ Lat, $6^{\circ} 52^{\prime} \mathrm{I}$ Long). Coll. 1965 and subm. by H. Elhaï.

Gif-404. Ballon d'Alsace, Fagne de la $3650 \pm 200$ Savoureuse 1700 B.C.

$0.90 \mathrm{~cm}$ to $1 \mathrm{~m}$ depth.

Gif-405. Ballon d'Alsace, Fagne de la $3800 \pm 200$ Savoureuse 1850 B.C.

$2.40 \mathrm{~m}$ to $2.50 \mathrm{~m}$ depth.

$4780 \pm 250$

Gif-406. Ballon d'Alsace, Grande Goutte

2830 B.C.

$4.80 \mathrm{~m}$ to $4.90 \mathrm{~m}$ depth.

General Comment: in good agreement with pollen analysis. N.B. rapid peat formation ca. 3700 B.P.

\section{Andlau marsh series, Bas Rhin}

Peat from basal level of peat bog formed in alluvial deposit of Andlau marsh. Coll. 1964 and subm. 1965 by M. Schaeffer, Fac. Sci. Orsay.

Gif-500. Innenheim, A 13-A/GO-14

$5920 \pm 150$

$\left(48^{\circ} 29^{\prime} \mathrm{N}\right.$ Lat, $7^{\circ} 35^{\prime} \mathrm{E}$ Long)

3970 B.C.

Gif-501. Meistrazheim, M (45) a

$5130 \pm 150$

(48 $27^{\prime} \mathrm{N}$ Lat, $7^{\circ} 32^{\prime} \mathrm{E}$ Long)

3180 B.c.

Volcanism series, Massif Central

Gif-486. Puy du Montchier

$8540 \pm 300$

6590 в.c.

Plant debris found at $1 \mathrm{~m}$ depth on hillside of Puy under layer of volcanic cinders, Puy de Montchier (45 $45^{\prime} \mathrm{N}$ Lat, $3^{\circ} 08^{\prime}$ E Long) Puy 
de Dôme. "Puy" or "Dome" are special designations for volcanoes on E side of Massif Central. Coll. and subm. 1965 by R. Brousse, Fac. Sci. Orsay. Comment: dates volcanic eruption which carbonized plants; emission of volcanic cinders being mostly domitic, formation of dome can be dated (Brousse et al., 1966).

\section{Gif-721. Col de la Moreno, Massif Central}

Carbonized oak found under $2.80 \mathrm{~m}$ ashes (trachytic), Col de la Moreno (45 ${ }^{\circ} 44^{\prime} \mathrm{N}$ Lat, 2 $56^{\prime} \mathrm{E}$ Long), Puy de Dôme. Coll. 1966 and subm. A. Rudel, Ecole Normale, Clermont-Ferrand.

General Comment: age and date of Gif-486 are comparable to date of Sa-94: $8580 \pm 350$ B.P. (Radiocarbon, 1964, v. 6, p. 239): these 3 samples date with certainty one of last great eruptions of "Chaine des Puys" in Massif Central. Most of lavas, lapilli, or cinders emitted by these volcanoes, either acidic or basic were emitted ca. 8500 yr ago.

\section{Passe-Castillonnaise series, Gironde}

Marine shell samples from "Passe-Castillonnaise," in Gironde estuary. "Passe-Castillonnaise" is ancient littoral band of shelly sand, separating existing alluvial plain of Mattes from Bas-Médoc. Coll .and subm. 1966 by P. Dutil, Stat. Agron. de Chalons-sur-Marne.

Gif-542. "La Fosse," Saint-Vivien de Médoc
$\left(45^{\circ} 26^{\prime} \mathrm{N}\right.$ Lat, $1^{\circ} \mathrm{W}$ Long), 50 to $65 \mathrm{~cm}$ depth.

\section{Gif-543. "Les Cabireaux," Talais}

( $45^{\circ} 29^{\prime} \mathrm{N}$ Lat, $1^{\circ} 04^{\prime} \mathrm{W}$ Long), 40 to $50 \mathrm{~cm}$ depth.

General Comment: date step in formation of estuary of Gironde R., and show that present shape of $\mathrm{S}$ side of estuary is almost unchanged since that time.

\section{Gif-347. Saint-Léger en Yvelines}

Phragmites peat, $60 \mathrm{~cm}$ depth, from filled ancient pond, at SaintLéger en Yvelines (48 $38^{\prime} \mathrm{N}$ Lat, $1^{\circ} 50^{\prime} \mathrm{E}$ Long), in Rambouillet forêt, $30 \mathrm{~km} \mathrm{~S}$ of Paris. Coll. 1964 and subm. by G. Jalut through M. Van Campo, Mus. d'Hist. Nat., Paris. Comment (G.J.): agrees well with pollen analysis which dated this level from transition between Atlantic and Sub-Boreal periods. Places more precisely in middle Atlantic period lst deforestations observed in pollen diagram.

\section{Gif-348. Belle-Ile-en-Mer}

$2680 \pm 200$

730 B.C.

Peat, $80 \mathrm{~cm}$ depth, in submerged boring, $5 \mathrm{~m}$ under high tides at "Ster-Vras" in Belle-Ile (47 $20^{\prime} \mathrm{N}$ Lat, $3^{\circ} 10^{\prime} \mathrm{W}$ Long). Coll. by N. Planchais and subm. by M. Van Campo. Comment (N.P.): pollen analysis revealed presence of Sub-Atlantic moor succeeding to poorly forested vegetation, probably related to end of Sub-Boreal period. Confirms local 
recent subsidence already observed in Saint-Jacques gulf of $\mathrm{S}$ coast of Bretagne (Sa-190, Radiocarbon, 1964, v. 6, p. 235, 2350 $\pm 150,4 \mathrm{~m}$ under high sea level).

\section{Gif-750. Camaret, Finistère}

$$
\begin{aligned}
& 24,400 \pm 1500 \\
& 22,450 \text { в.C. }
\end{aligned}
$$

Peaty level between 2 solifluction flows at Camaret, Finistère $\left(48^{\circ} 16^{\prime}\right.$ $\mathrm{N}$ Lat, $4^{\circ} 37^{\prime} \mathrm{W}$ Long). Coll. and subm. 1966 by M. T. Morzadec, Fac. Sci., Rennes. Comment: according to pollen analysis (Alnus dominant, Abies on top) peat horizon originates from interglacial period; date confirms it is Paudorf interstadial.

$$
\text { B. Africa }
$$

\section{Gif-320. Bassin of La Tafaina, Madagascar}

$11,580 \pm 400$

9630 B.c.

Humus $30 \mathrm{~cm}$ below soil covering, from upper terrace, in Basin of La Tafaina $\left(19^{\circ} 09^{\prime} \mathrm{S}\right.$ Lat, $47^{\circ} 29^{\prime} \mathrm{E}$ Long), Madagascar. This upper terrace is constituted by first generation of "Lavaka"; lavaka is a Madagascan name to design large circular excavations in lateritic clay, a result of process of gully erosion (Petit and Bourgeat, 1966). Coll. and subm. 1964 by J. Riquier, Office de Recherche Sci. et Techn. Outre Mer, Brazzaville, Congo. Comment: dates transition between alluvial and erosion phases. Corresponds to drier time between Gamblian and Makalian in Africa.

\section{Delta of Senegal series}

Marine shells (Arca senilis) from SW of Senegal's delta. Shelly layers were found in deltaic terraces, between sandy deposits. Coll. and subm. 1964 by P. Michel, Dept. Geog., Fann, Dakar, Sénégal.

\section{Gif-362. Delta du Sénégal, 911 a}

$5050 \pm 250$

Shelly horizon $1.5 \mathrm{~m}$ thick, in littoral strandline $\left(15^{\circ} 56^{\prime} \mathrm{N}\right.$ Lat, $16^{\circ} 27^{\prime}$ W Long); alt +2.70 m. Comment (P.M.): by alt and facies, deposit appears as kitchen midden on ancient offshore bar in gulf of Nouakchott.

\section{Gif-364. Delta du Sénégal, 921}

$$
1790 \pm 120
$$

$\left(15^{\circ} 54^{\prime} \mathrm{N}\right.$ Lat, $16^{\circ} 28^{\prime} \mathrm{W}$ Long). Shells from loc. as Gif-362; alt + $2 \mathrm{~m}$. Comment: same as for Gif-362.

\section{Gif-363. Delta du Sénégal, 918}

$1620 \pm 130$

Shelly level, $70 \mathrm{~cm}$ thick, from low terrace $\left(15^{\circ} 54^{\prime} \mathrm{N}\right.$ Lat, $16^{\circ} 29^{\prime}$ $\mathrm{W}$ Long), in lagoon, alt $+1.5 \mathrm{~m}$. Comment: dates natural deposit in lagoon between 2 offshore bars, W. Diarher.

\section{Trou au Natron series, Tibesti, Tchad}

“Trou au Natron" (20 $58^{\prime} \mathrm{N}$ Lat, $16^{\circ} 33^{\prime} \mathrm{E}$ Long) at ca. 2,200 m alt in Tibesti, SE Sahara. This huge caldera (depth: $650 \mathrm{~m}$, surface: $40 \mathrm{sq} . \mathrm{km}$ ) formed by subsidence following emission of big ignimbrite masses (H.T.), was formerly filled by a lake, recorded by lacustrine sedi- 
ments. Samples coll. 1965 by H. Tazieff, Mission Volcanol. du Tibesti and subm. by H. Faure, Fac. Sci. de Dakar, Sénégal.

\section{Gif-378. Trou au Natron, 4537}

$12,400 \pm 400$

Calcareous crusts on lava blocks of SW wall, $500 \mathrm{~m}$ under edge of caldera; alt $1775 \mathrm{~m}$.

\section{Gif-379. Trou au Natron, $\mathbf{4 5 4 5}$}

$14,790 \pm 400$

12,840 в.C.

Tiny gastropods in calcareous diatomite ca. $30 \mathrm{~m}$ above floor of crater; alt $1580 \mathrm{~m}$.

Gif-380. Trou au Natron, 4546

$14,970 \pm 400$

Gastropods in calcareous diatomite from upper terrace, $425 \mathrm{~m}$ to 400 $\mathrm{m}$ under SW edge of caldera; alt $1850 \mathrm{~m}, 1 \mathrm{~m}$ from top of diatomite zone. General Comment: diatomites from upper terrace and bottom are of same period, 14,790 and 14,970 B.P.; they are deposits of same lake more than $350 \mathrm{~m}$ deep. Age of calcareous crust (12,400 B.P.) appears satisfactory: this calcareous deposit should have begun $2500 \mathrm{yr}$ later, when concentration in water was higher because of evaporation. Dates agree with age of lacustrine period in Nigeria ( $T$ 338, Radiocarbon, 1964, v. 6, p. 286; Faure et al., 1963).

\section{Miscellaneous}

\section{Gif-321. Irazu volcano, Costa Rica}

Charcoal found at foot of Irazu volcano under large andesitic volcanic flow, Rio Reventazon, Costa Rica $\left(10^{\circ} \mathrm{N}\right.$ Lat, $85^{\circ} \mathrm{W}$ Long). Coll. 1964 by Jorge Umana and subm. by H. Tazieff, 15 quai Bourbon, Paris. Comment: recent eruptions discharged only fine ash and bombs. Confirms eruption dated by W-1548: 13,800 \pm 300 в.P. (Radiocarbon, 1967, v. 9, p. 526) is not last flow of Irazu volcano.

\section{Lac Saint-Jean Area series, Quebec}

Fossil shells from lac Saint-Jean Area, Quebec, coll. 1965 and subm. 1966 by P. Lasalle, Dept. Nat. Res., Quebec.

\section{Gif-423. Deshiens, Quebec, Canada}

$9560 \pm 350$

7610 B.C.

Shells (Macoma baltica) from pit opened in deltaic sand at mouth of Metabetchouan R., S of Lake Saint-Jean, Quebec ( $48^{\circ} 24^{\prime} 42^{\prime \prime}$ N Lat, $71^{\circ} 58^{\prime} 24^{\prime \prime}$ W Long); alt $119 \mathrm{~m}$.

\section{Gif-400. Metabetchouan, Quebec, Canada}

Shells (Macoma baltica, Portlandia arctica, and Hiatella arctica) from reworked outwash in gravel pit $\left(48^{\circ} 25^{\prime} 30^{\prime \prime} \mathrm{N}\right.$ Lat, $71^{\circ} 50^{\prime} \mathrm{W}$ Long); alt $153 \mathrm{~m}$. 
Gif-424. Metabetchouan, Quebec, Canada

$10,250 \pm 350$ 8300 в.C.

Shells (Macoma baltica) from shallow cut in sandy reworked outwash (48 $26^{\prime} \mathrm{N}$ Lat, $71^{\circ} 51^{\prime} \mathrm{W}$ Long), alt $113 \mathrm{~m}$.

Gif-401. Saint-Bruno, Prov. Quebec, Canada

$$
11,000 \pm 350
$$

9050 B.C.

Shells (Hiatella arctica) from shallow water sediments (probably reworked outwash or reworked till) of Champlain Sea $\left(45^{\circ} 33^{\prime} 25^{\prime \prime} \mathrm{N}\right.$ Lat, $73^{\circ} 19^{\prime} 20^{\prime \prime}$ W Long); alt ca. $135 \mathrm{~m}$.

General Comment (P.L.): Gif-424 is oldest date obtained on marine shells from Lake Saint-Jean dist.; is minimum for deglaciation. Date is minimum also for position of ice front at present location of assumed Saint-Narcisse moraine extension S of Lake Saint-Jean. Gif-400 and Gif423 date same episode of marine invasion in Lake Saint-Jean dist. Gif401 agrees with other dates obtained from fossil marine shells of Champlain Sea (Lasalle and Rondot, 1967).

\section{Gif-377. Island of Bali, Indonesia}

$22,000 \pm 1500$

Carbonized wood under ignimbrite from caldera of Batur, $10 \mathrm{~km}$ diam, near village of Marga $\left(8^{\circ} 27^{\prime} \mathrm{S}\right.$ Lat, $115^{\circ} 11^{\prime} \mathrm{E}$ Long), Is. of Bali, Indonesia. Coll. by G. Marinelli and subm. 1965 by H. Tazieff. Comment: dates formation of caldera.

\section{Gif-373. Phnom-Penh, Cambodia}

$5920 \pm \mathbf{3 0 0}$ 3970 B.C.

Peaty layer, 14 to $14.4 \mathrm{~m}$, alt $-4 \mathrm{~m}$, in boring of Bassac, Phnom-Penh (11 $1^{\circ} 35^{\prime} \mathrm{N}$ Lat, $104^{\circ} 55^{\prime} \mathrm{E}$ Long), Cambodia. Coll. by Soc. Française des Dragages and subm. 1965 by J. P. Carbonnel, Fac Sci. Paris. Comment: dates cambering of this region which separates Great Lake of Cambodia from Mekong delta. Compare Sa-237, 5720 B.P. (Radiocarbon, 1965, v. 7, p. 243) which dated beginning of present sedimentation in Great Cambodia Lake; present structure is supposed to result chiefly from tectonic movement.

\section{Spitsbergen series}

\section{Gif-385. Spitsbergen 1}

$9560 \pm 350$

7610 B.C.

Whale bone from upraised beach at $+6 \mathrm{~m}$ alt, Kwadelanke point, Baie du Roi, Spitsbergen (79 $40^{\prime} \mathrm{N}$ Lat, $11^{\circ} 40^{\prime} \mathrm{E}$ Long). Coll. and subm. 1965 by P. Gabert, Fac. Lettres d'Aix-en-Provence, Bouches du Rhône.

Gif-894. Sarsöya, Spitsbergen

$9600 \pm 220$

7650 B.c.

Shells of bivalves, taken in situ from marine silty sand, $1.50 \mathrm{~m}$ above high tide, at Sarsöya, Spitsbergen $\left(78^{\circ} 48^{\prime} \mathrm{N}\right.$ Lat, $12^{\circ} 12^{\prime} \mathrm{W}$ Long). Coll. and subm. by A. Guilcher, Inst. Geog., Paris. 
General Comment: ages identical with those found for terraces at + $11 \mathrm{~m}$, Gif-317: $9260 \pm 350,+13 \mathrm{~m}$, Gif-318: $9350 \pm 350,+20 \mathrm{~m}$, Gif319: $9650 \pm 50$ (Radiocarbon, 1966, v. 8, p. 91); confirm rapid isostatic uplift ca. 9000 B.P. of this part of Spitsbergen coast.

II. CORAL FROM PACIFIC ATOLLS

During experimental drilling in 1964 by French A.E.C. in Mururoa atoll, Tuamotu Is., continuous cores of coral were extracted. $\mathrm{C}^{14}$ measurements were done on upper part of 2 cores: "Colette" core, which reached basalt at $438 \mathrm{~m}$, and "Anémone" only $20 \mathrm{~m}$ deep. Deep samples were dated by $\mathrm{Th} / \mathrm{U}$. Dated samples are related to mean sea level, at \pm 0.2 $\mathrm{m}$ for "Colette" core and $\pm 0 \mathrm{~m}$ for "Anémone." Subm. 1965 by J. Labeyrie.

Gif-621. Living coral $+3 \%$

( $17^{\circ} 40^{\prime} \mathrm{S}$ Lat, $149^{\circ} 30^{\prime} \mathrm{W}$ Long). Living coral, at $-2 \mathrm{~m}$ along seaward side of $\mathrm{N}$ reef of Tahiti. Subm. 1965 by J. Labeyrie. Comment: carbon activity of sea water in region is not measured; may be compared to Oceanic measurements of sea water off California in 1965: +8 to $+12 \%$ (Radiocarbon, 1966, v. 8, p. 467-497).

Colette series

Coral core, $\mathrm{N}$ part of ring of Mururoa atoll $\left(21^{\circ} 47^{\prime} \mathrm{S}\right.$ Lat, $138^{\circ} 54^{\prime}$ W Long); alt $+0.8 \mathrm{~m}$.

Gif-634. "Colette", surface, $+0.80 \mathrm{~m}$, massive coral

$3020 \pm 200$

Gif-622. "Colette", $-1 \mathrm{~m}$, sand and fragments
of coral

1070 B.c.

$5300 \pm 300$

3350 B.c.

Gif-624. "Colette", $-3 \mathrm{~m}$, sand and fragments of coral

$5880 \pm 300$

3930 в.C.

Gif-625. "Colette", $-5.4 \mathrm{~m}$, sand and fragments of coral

$4990 \pm 300$

3040 B.C.

Gif-636. "Colette", $-6.1 \mathrm{~m}$, massive coral

$5420 \pm 300$

3740 B.C.

Gif-626. "Colette", $-7 \mathrm{~m}$, massive coral

$\geqslant 25,000$

Gif-627. "Colette", $-9 \mathrm{~m}$, sand and fragments of coral

$\geqslant 30,000$

Gif-628. "Colette", $-20 \mathrm{~m}$, sand and fragments

$\geqslant 30,000$ of coral

\section{Anemone series}

Coral core, E part of ring of Mururoa atoll (21 $51^{\prime} \mathrm{S}$ Lat, $138^{\circ} 47$ W Long); alt $+3 \mathrm{~m}$. 
Gif-629. "Anemone", surface, $+3 \mathbf{~ m}$,
massive coral

Gif-630. "Anemone", sea level, sand and coral fragments

Gif-631. "Anemone", $-1 \mathrm{~m}$, conglomerate (sand and coral fragments)

Gif-632. "Anemone", $-3 \mathrm{~m}$, massive coral

Gif-633. "Anemone", $-5 \mathrm{~m}$, massive coral

Gif-637. "Anemone", $-7 \mathrm{~m}$, conglomerate and sand
$3610 \pm 200$

1160 B.C.

$2910 \pm 200$

960 в.c.

$5550 \pm 300$

3600 B.c.

$5600 \pm 300$

3650 B.C.

$8200 \pm 350$

6250 B.C.

$17,300 \pm 800$

15,350 в.c.

$\geqslant \mathbf{3 0 , 0 0 0}$

Gif-638. "Anemone", $-9 \mathrm{~m}$, massive coral

General Comment: very similar results obtained by Thurber et al. (1965), for Eniwetok atoll $\left(12^{\circ} \mathrm{N}, 162^{\circ} \mathrm{E}\right), 8,500 \mathrm{~km}$ off Mururoa; suggests that level fluctuations observed are due not to local crustal movements but to eustatic phenomena. At Mururoa, local subsidence rate is negligible: $6 \mathrm{~cm}$ per $1000 \mathrm{yr}$ as mean value averaged over $7 \times 10^{6} \mathrm{yr}$. Several important steps in eustatic sea levels may be deduced:

1) at ca. $-7 \mathrm{~m}$ appears an old surface of atoll, pre-Würm (dated at 120, 000 to $160,000 \mathrm{yr}$ by $\mathrm{Th}^{230} \mathrm{U}^{234}$, Labeyrie et al., 1968). At that time, surface was a few $\mathrm{m}$. above, or at present sea level.

2) this level became submerged at ca. 8000 B.P.

3) very rapid rise of sea level occurred at ca. 5500 в.P., from ca. $-6 \mathrm{~m}$ to $-1 \mathrm{~m}$.

4) rapid rise seems to have occurred at ca. 3000 to 3600 в.P. bringing sea level to $+3 \mathrm{~m}$.

5) rough following recent history of atolls may be suggested: majority of Pacific and Indian Ocean atolls emerged during Würm's cold period, submerged from 8000 to 5000 B.P., then emerged for short time, then submerged again until 3500 B.P., and emerged again.

Alt. over present sea level of all atolls must be $3 \mathrm{~m}$ at uppermost.

\section{CAVE CALCAREOUS FORMATIONS}

Formation of cave deposits in limestone is due to well known mechanism: seepage waters dissolve biogenic $\mathrm{CO}^{2}$ in biologically active layers of soil and are able to dissolve some $\mathrm{Ca} \mathrm{CO}^{3}$ from limestone. If this water containing $\mathrm{Ca}, \mathrm{CO}^{2}, \mathrm{CO}^{3} \mathrm{H}^{-}$, and $\mathrm{CO}^{3--}$ ions in equilibrium emerges into cave, most $\mathrm{CO}^{2}$ escapes from water and $\mathrm{Ca} \mathrm{CO}^{3}$ precipitates as stalactites, stalagmites, or other calcareous structures. Only part of carbon of these deposits is of biogenic origin; our preliminary experiments in laboratory show that 1 out of 3 carbon atoms comes from limestone, and therefore activity of recent calcareous deposits should be depleted by ca. 
$34 \%$ of recent biogenic carbon activity. This proportion seems fairly independent of temperature variations, as long as acid carbonic solution is saturated with calcium carbonate. This has been confirmed by measuring $\mathrm{C}^{14}$ activity of 2 recent stalagmites, grown in 2 caves differing widely in climatic conditions; the 1st from Orgnac, relatively hot $\left(12.6^{\circ} \mathrm{C}\right)$ dry country; the 2nd from Grange-Mathieu, cooler $\left(10^{\circ} \mathrm{C}\right)$ and very humid country, Jura, France. Chemical measurements on 401 . of cave water dropping on big stalagmite in Orgnac, gave $33 \mathrm{mg} / 1$ of limestone carbon and $63 \mathrm{mg} / 1$ of biogenic carbon.

\section{A. Direct determination of biogenic carbon proportion}

Results are given in $\delta \%$ vs 0.95 NBS oxalic acid.

Stalagmite D series, Orgnac, Ardèche, upper part

In lst Room A of "New Orgnac" cave, communicating with Aven d'Orgnac cave $\left(44^{\circ} 18^{\prime} \mathrm{N}\right.$ Lat, $4^{\circ} 26^{\prime} \mathrm{E}$ Long); alt $200 \mathrm{~m}$; thickness of limestone above room: ca. $70 \mathrm{~m}$. Big white stalagmite in pure calcite, $2.20 \mathrm{~m}$ long, $85 \mathrm{~mm}$ diam, taken in situ. Coll. 1966 by J. C. Duplessy and G. Delibrias, G. F. R., C. N. R. S., Gif-sur-Yvette.

Gif-616. Head, $S 8$

Superficial level, ca. $1 \mathrm{~mm}$ thick, filed off.

Gif-618. Head, S 10

Second superficial level, ca. $1 \mathrm{~mm}$ thick, filed off. $\delta C^{13}=-10.61 \%$ General Comment: these 2 dates indicate within 2\% same proportion as lab experiments, Stalagmite was almost dry, which explains why nuclear explosion $\mathrm{C}^{14}$ increase is not apparent.

Gif-609. Air of Room A, January 1966 $+11 \%$

$\mathrm{CO}^{2}$ coll. by slow bubbling through solution of $\mathrm{Ba}(\mathrm{OH}) 2$. Comment: during end of 1965, oak leaves from ground above cave are much more enriched in $\mathrm{C}^{14}: 83 \%$. Air of Room $\mathrm{A}$ is in slow exchange with free atmosphere; residence time is at least several yr.

Gif-608. Water of stalactite of same Room $A$ $-4 \%$

$\mathrm{CO}^{2}$ and bicarbonates dissolved in $40 \mathrm{l}$. water dropping along stalactite, with large surface of exchange with ambiant air. Comment: residence time of water in upper limestone layers of this room is at least several yr.

Gif-617. Small formations, S 9, Orgnac

Small and fine stalactites 1 and $2 \mathrm{~cm}$ long formed from Nov. 1965 to Jan. 1966, at entrance of Aven d'Orgnac cave. Comment: in this part, air is exchanged quickly and residence time of dropping water is probably short. From this and from $\mathrm{C}^{14}$ enrichment of tree leaves in same region $(+83 \%$ for 1965$)$, biogenic carbon content is $63 \%$.

\section{Stalagmite B, Grange-Mathieu series, Jura, upper part}

Cave of Grange Mathieu ( $47^{\circ} 09^{\prime} \mathrm{N}$ Lat, $5^{\circ} 59^{\prime} \mathrm{E}$ Long); alt $300 \mathrm{~m}$; thickness of limestone above room: ca. $15 \mathrm{~m}$. Large white calcite stalag- 
mite, $5.50 \mathrm{~m}$ long, $130 \mathrm{~mm}$ diam at bottom, $95 \mathrm{~mm}$ at top, $\mathrm{W}$ of entrance pit in Room C. Sawed out at base. Coll. 1967 by J. C. Duplessy, D. Nordemann, and J. Labeyrie, C. F. R., C. N. R. S., Gif-sur-Yvette.

Gif-652. A B I, head

Superficial layer, $1 \mathrm{~mm}$ thick, filed off.

$$
\begin{array}{r}
+\mathbf{1 8 . 5 \%} \\
\delta C^{13}=-7.20 \% \\
+\mathbf{2 1 \%} \\
\delta C^{13}=-7.75 \% \\
+\mathbf{7} \% \\
\delta C^{13}=-7.36 \% \\
+\mathbf{3 . 5 \%} \\
-\mathbf{3 6 . 5 \%} \\
\delta C^{13}=-8.08 \% \\
\mathbf{- 3 4 . 5 \%} \\
\delta C^{13}=-8.69 \% \\
-\mathbf{3 6 \%} \\
\delta C^{13}=-8.66 \%
\end{array}
$$$$
\text { 2nd layer, } 1 \mathrm{~mm} \text { thick, filed off. }
$$$$
\text { Gif-661. A B I (1), } 3 \mathrm{~cm} \text { from top }
$$$$
\text { Gif-664. A B I (2), } 8 \mathrm{~cm} \text { from top }
$$$$
\text { Gif-666. A B I (11), } 54 \mathrm{~cm} \text { from top }
$$$$
\text { Gif-653. A B I (12), } 64 \mathrm{~cm} \text { from top }
$$$$
\text { Gif-667. A B II (1), } 70 \mathrm{~cm} \text { from top }
$$

General Comment: for at least $25 \mathrm{yr}$ this stalagmite has been in wellaerated room with relatively large (cross section $2 \mathrm{~m}^{2}$, length $30 \mathrm{~m}$ ) horizontal connection with bottom of entrance pit (depth $25 \mathrm{~m}$, cross section $200 \mathrm{~m}^{2}$ ). Same proportion of biogenic carbon vs. limestone carbon as in Orgnac is found in upper part of this stalagmite, except for top, obviously enriched with bomb $\mathrm{C}^{14}$. See below apparent ages of remnant sections of this stalagmite.

Gif-663. Elder leaves, Grange Mathieu

Remains of elder leaves grown in 1966. Coll. March 1967, to determine $\mathrm{C}^{14}$ enrichment in plants, just above cave.

\section{B. Dating of levels in cave stalagmites}

From above measurements, proportion of biogenic carbon in pure calcite stalagmite is considered $65 \%$ throughout their formation, for both caves of Orgnac and Grange-Mathieu.

\section{Stalagmite D series, Orgnac}

Gif-614. V, S 6

$1320 \pm 250$

A.D. 630

$270 \mathrm{~mm}$ from head, sampling in center of stalagmite. $\delta C^{13}=-10.77 \%$

\section{Gif-615. V S 7}

$1200 \pm 250$

$270 \mathrm{~mm}$ from head, sampling from external part of stalagmite. Comment: cylindrical stalagmite, probably formed of successive horizontal layers. If compared to Gif-614, difference in dates is not statistically signifi- 
cant and results do not imply difference between age of external part and center of stalagmite.

Gif-619. II, S 12

$2850 \pm 300$

$660 \mathrm{~mm}$ from head.

Gif-643. III-4, S 19

900 B.C.

$880 \mathrm{~mm}$ from head.

$4160 \pm 350$

2210 B.c.

Gif-611. III, S 3

$400 \pm 350$

$1.16 \mathrm{~mm}$ from head.

2450 B.c.

$\delta C^{13}=-10.03 \%$

Gif-612. II, S 4

$5650 \pm 400$

3700 B.C.

$\delta C^{13}=-9.93 \%$

$6480 \pm 400$

Gif-613. I, S 5

4530 в.C.

$2.06 \mathrm{~m}$ from head, at base of stalagmite.

$\delta C^{13}=-9.22 \%$

General Comment: dates permit calculation of mean growth rate of 32 $\mathrm{mm} / 100 \mathrm{yr}$. However, this rates varies all along stalagmite and seems to have been more rapid ca. 4000 B.P.: ca. $90 \mathrm{~mm}$ in $100 \mathrm{yr}$; at present it seems very slow $(<20 \mathrm{~mm}$ in $100 \mathrm{yr})$ : this stalagmite is almost "dead" (J. Labeyrie et al., 1967).

\section{Stalagmite $C$ series, Orgnac}

In same room as Stalagmite D; "living" white stalagmite of pure calcite, $370 \mathrm{~mm}$ long ,60 $\mathrm{mm}$ diam., sawed in place.

Gif-640. Head, 1st surface layer, $\mathrm{S} 15$

Cia. 1 mm thick.

Gif-641. Head, 2nd layer, S 16

Ca. $1 \mathrm{~mm}$ thick.

Gif-642. Head, 3rd layer, S 18

Ca. $1 \mathrm{~mm}$ thick.

Gif-610. Base, S 1

$6800 \pm 230$

4850 B.C.

General Comment: it is not clear whether superficial layers are contaminated by bomb $\mathrm{C}^{14}$. More measurements are necessary.

\section{Reddish stalagmites series, Orgnac}

Sampling on red stalagmite, found broken and lying on ground.

Gif-639. Reddish Stalagmite 1, S 14

$-89 \%$

Head, superficial layer. 
Gif-620. Reddish Stalagmite 1, S 13

Bottom.

Gif-651. Reddish Stalagmite 2, S 17

Head, superficial layer.

Gif-690. Reddish Stalagmite 3

$-92 \%$

Bottom.

General Comment: reddish stalagmites are very old, and made of thin layers of calcite intercalated with colloidal red clay, probably present in dropping water.

Stalagmite B series, Grange-Mathieu

Gif-668. A B II (2), $76.5 \mathrm{~cm}$ from top

Gif-669. A B II (3), $83 \mathrm{~cm}$ from top

Gif-672. A B II (6), $91 \mathrm{~cm}$ from top

Gif-673. A B II (8), $96 \mathrm{~cm}$ from top

Gif-674. A B II (10), $1.02 \mathrm{~m}$ from top

Gif-675. A B II (12), $1.07 \mathrm{~m}$ from top

Gif-676. A B II (14), $1.12 \mathrm{~m}$ from top

Gif-654. A B II (15), $1.15 \mathrm{~m}$ from top

Gif-678. C (2), $1.26 \mathrm{~m}$ from top

Gif-679. C (4), $1.36 \mathrm{~m}$ from top $\mathbf{5 1 0} \pm \mathbf{1 4 0}$
A.D. 1440
$\delta C^{13}=-9.93 \%$
$\mathbf{7 0 0} \pm \mathbf{1 4 0}$

A.D. 1250

$\delta C^{13}=-8.75 \%$

$500 \pm 140$

A.D. 1540

$\delta C^{13}=-7.68 \%$

$310 \pm 140$

A.D. 1640

$\delta C^{13}=-8.85 \%$

$800 \pm 140$

A.D. 1150

$\delta C^{13}=-6.96 \%$

$860 \pm 140$

A.D. 1090

$\delta C^{13}=-7.00 \%$

$630 \pm 140$

A.D. 1320

$\delta C^{13}=-6.25 \%$

A.D. 1070

$880 \pm 140$

$\delta C^{13}=-9.86 \%$

$850 \pm 140$

A.D. 1100

$\delta C^{13}=-8.35 \%$

$1020 \pm 140$

A.D. 930

$\delta C^{13}=-7.49 \%$ 
Gif-680. C (6), $1.48 \mathrm{~m}$ from top

Gif-681. C (10), $1.70 \mathrm{~m}$ from top

Gif-656. C (13), $1.87 \mathrm{~m}$ from top

Gif-682. D (2), $1.97 \mathrm{~m}$ from top

Gif-683. D (5), $2.11 \mathrm{~m}$ from top

Gif-684. D (7), $2.21 \mathrm{~m}$ from top

Gif-657. D (9), $2.31 \mathrm{~m}$ from top

Gif-677. E F 11, 2.97 $\mathrm{m}$ from top

Gif-659. E F IV, $3.63 \mathrm{~m}$ from top

Gif-687. G 1 (2), $3.97 \mathrm{~m}$ from top

Gif-658. G I (4), $4.31 \mathrm{~m}$ from top

Gif-688. G II (a), $4.62 \mathrm{~m}$ from top

Gif-655. G II (b), $5.00 \mathrm{~m}$ from top
$1130 \pm 140$ A.D. 820

$\delta C^{13}=-9.57 \%$

$2030 \pm 140$

80 B.c.

$\delta C^{13}=-7.45 \%$

$2000 \pm 140$

50 в.c.

$\delta C^{13}=-9.00 \%$

$2080 \pm 150$

130 B.C.

$\delta C^{13}=-7.58 \%$

$2390 \pm 150$

440 в.C.

$\delta C^{13}=-6.40 \%$

$2480 \pm 150$

530 в.C.

$\delta C^{13}=-6.50 \%$

$2630 \pm 150$

680 B.C.

$\delta C^{13}=-8.67 \%$ 。

$3890 \pm 170$

1940 B.c.

$\delta C^{13}=-8.80 \%$

$5250 \pm 200$

3300 B.C.

$6300 \pm 230$

4350 в.C.

$\delta C^{13}=-7.77 \%$

$5730 \pm 230$

3780 B.C.

$\delta C^{13}=-8.34 \%$

$6980 \pm 230$

5030 в.C.

$\delta C^{13}=-7.84 \%$

$7980 \pm 170$

6030 B.C.

$\delta C^{13}=-8.23 \%$

General Comment: same stalagmite as above (Stalagmite B). Artificial $\mathrm{C}^{14}$ still present at least $8 \mathrm{~cm}$ from top. From now to ca. 100 B.P., extremely rapid growth $(70 \mathrm{~cm} / 100 \mathrm{yr})$, supposedly due to sudden enlarge- 
ment of entrance of Room C by rockfall, creating a draught and rapid evaporation of water (relative humidity in Room C has same variations as in entrance peat, instead of being steadily ca. $100 \%$ as in Orgnac A and other rooms of Grange-Mathieu). Important perturbations between $76 \mathrm{~cm}$ and $1.15 \mathrm{~m}$ (very roughly ca. 700 B.P.) not yet explained. High speed between 800 B.P. and 1150 B.P., and between 2000 B.P. and 2200 B.P., low between 1200 B.P. and 2000 B.P. $(2.5 \mathrm{~cm} / 100 \mathrm{yr})$, roughly steady rate between 2200 B.P. and 8000 B.P. $(5.3 \mathrm{~cm} / 100 \mathrm{yr})$.

Date lists:

REFERENCES

Saclay

Saclay II

Gif II

Delibrias, Guillier, and Labeyrie, 1964

Delibrias, Guillier, and Labeyrie, 1965

Delibrias, Guillier, and Labeyrie, 1966

Trondheim IV

Nydal, Lövseth, Skullerud, and Holm, 1964

UCLA V

Berger and Libby, 1966

USGS IX Ives, Levin, Oman, and Rubin, 1967

Brousse, R., Delibrias, G., Labeyrie, J., and Rudel, A., 1966, Datation par la méthode du carbone 14 d'une éruption domitique de la Chaine des Puys: Acad. sci. [Paris] Comptes rendus, v. 263, p. 1812-1815.

Brun, A. and Blavoux, B., 1966, Caractéristiques sédimentologiques et palynologiques des terrains Würmiens de la région d'Evian d'après le sondage de Sionnex (Haute Savoie): Acad. sci. [Paris] Comptes rendus, v. 263, p. 212-215.

Brun, A. and Delibrias, G., 1967, Datation et caractéristiques palynologiques des sédiments glacieries de la Coupe d'Armoy (Haute Savoie): Acad. sci. [Paris] Comptes rendus, v. 264. p. 215-217.

Delibrias, G. and Larsonneur, C., 1966, Datation absolue de dépôts organiques Würmiens en Normandie: Acad. sci. [Paris] Comptes rendus, v. 263, p. 1022-1024.

Elhaï, H., 1960, La Tourbière de Gathémo (Manche-Normandie), Pollen et Spores, v. II, $\mathrm{n}^{\circ} 2$, p. $263-274$.

1962, Analyse pollinique d'un dépôt organique intercalé dans le Head d'Ecalgrain: Soc. Linn. Normandie Bull. ser 3, p. 93-95.

Faure, H., Manguin, E., and Nydal, R., 1963, Formations lacustres du quaternaire supérieur du Niger oriental: diatomites et âges absolus: Bur. Recherches Géol. et Minières Bull., ${ }^{\circ} 3$, p. 41-61.

Giresse, P., Dangeard, L., and Hommeril, P., 1967, Sur la présence de dépôts flandriens: Acad. sci. [Paris] Comptes rendus, v. 265, p. 1887-1890.

Labeyrie, J., Duplessy, J. C., Delibrias, G., and Letolle, R., 1967, Etude des températures des climats anciens par la mesure de l'Oxygène-18, du Carbone-13 et du Carbone-14 dans les concrétions des cavernes: Conference on Radioactive dating and methods of low-level counting, I.A.E.A., Vienna, SM-87/5.

Labeyrie, J., Lalou, C., and Delibrias, G., 1968, Etude des transgressions marines sur l'atoll de Mururoa par la datation des différents niveaux de corail: Cahiers du Pacifique, in press.

Lasalle, P. and Rondot, J., 1967, New ${ }^{14} \mathrm{C}$ dates from the Lac St-Jean area, Quebec: Canadian Jour. Earth Sci., v. 4, p. 568-571.

Petit, M. and Bourgeat, F., 1966, Etude morphologique du Bassin Versant de la Tafaïna: La Semaine Géol., Comptes Rendus, Imprimerie Nat. de Tananarive.

Serruya, C. and Sauvage, J., 1966, Stratigraphie tardi et post-glaciaires des sédiments du Lac Léman: Acad. sci. [Paris] Comptes rendus, v. 263, p. 2397-2400.

Thurber, D. L., Broecker, W. S., Blanchard, R. L., and Potratz, H .A., 1965, Uraniumseries ages of Pacific atoll coral: Science, v. 149, p. 55-58.

Van Straaten, L. M. J. U., 1965, Nederl. Gcol. Stricht., v. 17, p. 41. 